\title{
Assessment of Phosphorus Buffering Capacity of Drainage Canal Sediments in Paddy-Field Districts
}

\author{
Takehide HAMA $^{1)}$, Daichi IWASAKI ${ }^{2)}$, Chinami JIKUMARU ${ }^{1)}$, Yasunori KAWAGOSHI' ${ }^{1)}$, \\ Tomohisa NAGAI ${ }^{3)}$ \\ 1) Graduate School of Science and Technology, Kumamoto University, 2-39-1 Kurokami, \\ Chuo-ku, Kumamoto 860-8555, Japan \\ 2) Ministry of Agriculture, Forestry and Fisheries, 1-2-1 Kasumigaseki, Chiyoda-ku, Tokyo \\ 100-8950, Japan \\ 3) Graduate School of Agriculture, Kyoto University, Oiwake-cho, Kitashirakawa, Sakyo-ku, \\ Kyoto 606-8502, Japan
}

\begin{abstract}
Paddy-field areas are among the major non-point sources of phosphorus (P). Drainage canals can influence $\mathrm{P}$ concentration in drainage water because the sediments can absorb $\mathrm{P}$ and have large $\mathrm{P}$ buffering capacity. Assessment of the $\mathrm{P}$ buffering capacity and management of drainage canal sediments are important to reduce P effluent loadings from paddy-field areas. In this study, we investigated three paddy-field districts around Lake Biwa. Using adsorption and incubation experiments, we clarified the $\mathrm{P}$ adsorption and release characteristics of the sediments. The concentrations of total sedimentary $\mathrm{P}$ were highest in the surface layer of the sediments. The zero-equilibrium $\mathrm{P}$ concentrations of the sediments, estimated from the $\mathrm{P}$ adsorption experiment, varied widely among sites, and were similar to the peak concentrations of $P$ released from the incubated sediments and the mean P concentrations in the drainage water $(0.021$ to $0.068 \mathrm{mgP} / \mathrm{L})$. These results suggest that the sediments determine the concentrations of $\mathrm{P}$ in the overlying drainage water. Adsorption isotherms for dry sediments were described by a linear model with higher slope than wet sediments, indicating that drying drainage canals might enhance the $\mathrm{P}$ buffering capacity of sediments.
\end{abstract}

Keywords: buffering capacity, drainage canal sediment, paddy field, phosphorus

\section{INTRODUCTION}

Reduction of nutrient effluent loadings from agricultural lands, which are major non-point sources of nutrients, is the most important issue. In particular, reduction of phosphorus $(\mathrm{P})$ loadings is important because $\mathrm{P}$ is commonly a limiting factor for eutrophication (Sharpley, 1995). To reduce effluent loadings, increasing the retention time of pollutants in drainage canals is considered an effective measure (Hama et al., 2013). Agricultural drainage-ditch sediments had high $P$ retention capacities (Kröger et al., 2008; Smith, 2009). Therefore, effluent loadings can be decreased through deposition of suspended solids (SS) and adsorption of $\mathrm{P}$ by sediments in drainage canals or through uptake by plants if the retention time is long enough. However, it is necessary to appropriately manage the sediments in drainage canals to reduce effluent loadings (Barlow et al., 2006; Smith, 2009), because loosely bound P can be released into the overlying water under reducing conditions (Nguyen and Sukias, 2002; Iwasaki et al., 2013). In general, the water level and rate of drainage on farms and in downstream drainage canals are artificially controlled, and thus the sediments can play two contrasting functions, that is, drainage may enhance transport of P-rich runoff, or it may decrease waterlogging, which increases the soil redox potential, thereby promoting $\mathrm{P}$ adsorption and co-precipitation with iron complexes (Kröger et al., 2008).

Address correspondence to Takehide Hama, Graduate School of Science and Technology, Kumamoto University, Email: hama@kumamoto-u.ac.jp

Received May 18, 2014, Accepted September 16, 2014. 
Most studies have been conducted in upland fields. Accordingly, little is known about the $\mathrm{P}$ in the sediments in drainage canals of rice paddy fields. As the drainage canals in rice paddy fields are filled with water during the rice growing season, unlike those in upland fields, the sediments may have a greater influence on $\mathrm{P}$ in the overlying drainage water than in upland fields. Therefore, to evaluate the role of sediment in drainage canals as a $\mathrm{P}$ source or sink, it is important to evaluate the $\mathrm{P}$ adsorption characteristics of the sediment. This study aimed at clarifying the influence of drainage canal sediments on $\mathrm{P}$ concentrations in the drainage water in paddy-field districts.

\section{MATERIALS AND METHODS}

\section{Study site}

We studied three paddy-field districts around Lake Biwa, in Shiga Prefecture, Japan (Fig. 1, Table 1). The Yagihama district (Site 1, 35 $24^{\prime} \mathrm{N}, 136^{\circ} 13^{\prime} \mathrm{E}$ ), covering 13 ha, lies to the north of the lake at the lower end of Anegawa River. The mean annual temperature and rainfall are $13.9^{\circ} \mathrm{C}$ and $1,553 \mathrm{~mm}$, respectively (JMA, 2014). The irrigation and drainage canals are separate. The drainage canals are not lined with concrete and are submerged all year round. The Nomura district (Site 2, 35 $08^{\prime} \mathrm{N}, 136^{\circ}$ $02^{\prime} \mathrm{E}$ ), covering $7.9 \mathrm{ha}$, lies to the southeast of the lake at the lower end of Hinogawa

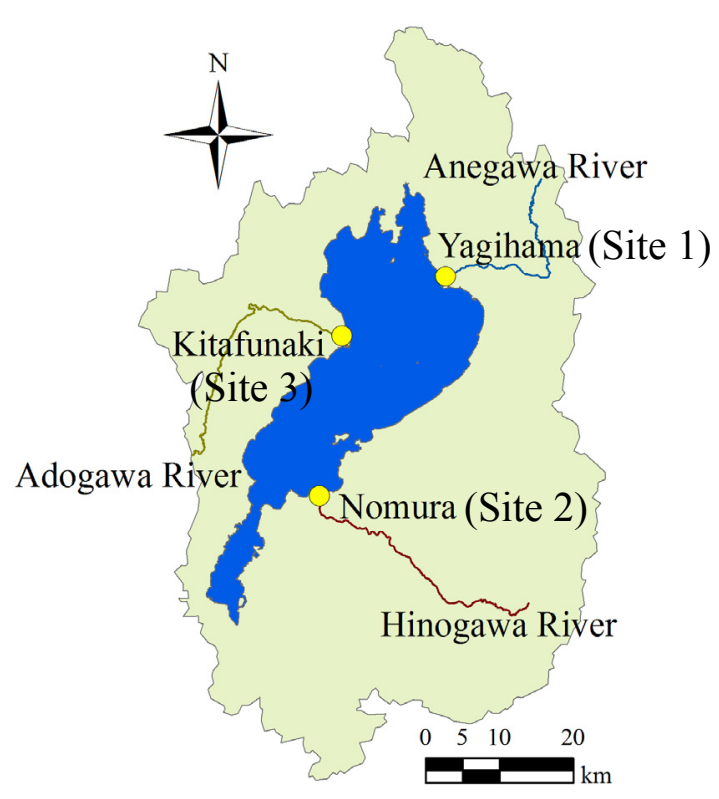

Fig. 1 - Location of study sites.

Table 1 - Outline of the study site.

\begin{tabular}{|c|c|c|c|c|}
\hline Site & Location & $\begin{array}{l}\text { Area } \\
{[\text { ha] }}\end{array}$ & $\begin{array}{c}\text { Irrigation and drainage } \\
\text { canal system }\end{array}$ & $\begin{array}{c}\text { Lining on } \\
\text { drainage canal }\end{array}$ \\
\hline 1 & $35^{\circ} 24^{\prime} \quad \mathrm{N}, 136^{\circ} 13^{\prime} \mathrm{E}$ & 13 & Separated & Wall lining \\
\hline 2 & $35^{\circ} 24^{\prime} \mathrm{N}, 136^{\circ} 13^{\prime}$ & 7.9 & Separated & Wall lining \\
\hline 3 & $35^{\circ} 20^{\prime} \quad \mathrm{N}, 136^{\circ} 04^{\prime}$ & 52.5 & Not-separated & No lining \\
\hline
\end{tabular}


River. The mean annual temperature and rainfall are $14.9^{\circ} \mathrm{C}$ and $1,530 \mathrm{~mm}$, respectively (JMA, 2014). The drainage and irrigation canals are separate. The drainage canals are lined with concrete, and sediment deposits at the bottom. The drainage canals are flooded during the rice growing season (irrigation period), from mid-April to late August, and are dry during the non-irrigation period, except on rainy days. The Kitafunaki district (Site 3, 35 $20^{\circ} \mathrm{N}, 136^{\circ} 04^{\prime} \mathrm{E}$ ), covering 52.5 ha, lies to the west of the lake at the lower end of Adogawa River. The mean annual temperature and rainfall are $14.9^{\circ} \mathrm{C}$ and $1,530 \mathrm{~mm}$, respectively (JMA, 2014). The drainage and irrigation canals are not separate, and the drainage canals are not lined with concrete. The drainage canals are submerged all year round.

\section{Field investigation}

Drainage water was sampled monthly at each site for two years since April 2011 and analyzed for $\mathrm{pH}$, suspended solids (SS), total P (T-P), total dissolved P (TD-P), and $\mathrm{PO}_{4}-\mathrm{P}$ (Hama et al., 2014). The $\mathrm{pH}$ was measured using a $\mathrm{pH}$ meter (D-54, Horiba Ltd., Tokyo, Japan). Samples were filtered through a $1 \mu \mathrm{m}$ filter and then SS was measured by weighing the filter after overnight drying in an oven at $110^{\circ} \mathrm{C}$. Total $\mathrm{P}$ and TD-P (after potassium-peroxydisulfate digestion) and $\mathrm{PO}_{4}-\mathrm{P}$ were measured by spectrophotometer using the molybdenum blue method (Murphy and Riley, 1962). Samples were filtered through a $0.45-\mu \mathrm{m}$ filter before analysis of TD-P and $\mathrm{PO}_{4}-\mathrm{P}$.

Sediments in the drainage canals were sampled with a core sampler in June (irrigation period) and November (non-irrigation period) in 2011 and 2012 (Table 2). The sediments were sliced into three layers $(0-1 \mathrm{~cm}, 1-5 \mathrm{~cm}$, and $5-10 \mathrm{~cm})$ in situ. The samples were packed into polyethylene bags and transported to the laboratory in a cooler box. The sed

iment samples were air-dried at $4^{\circ} \mathrm{C}$ in a refrigerator and then sieved through a $125-\mu \mathrm{m}$ sieve for analysis of the total sedimentary $\mathrm{P}$ (TSP). After ignition at $550^{\circ} \mathrm{C}$, TSP was extracted in $1 \mathrm{M} \mathrm{HCl}$ and measured as $\mathrm{PO}_{4}-\mathrm{P}$ by the molybdenum blue method. The water content in the sediment was estimated from the difference between the sediment weights before and after overnight drying in an oven at $110^{\circ} \mathrm{C}$.

Table 2 - Condition of the drainage canals on the sediment sampling day.

\begin{tabular}{|c|c|c|c|c|}
\hline Date & Period & Site 1 & Site 2 & Site 3 \\
\hline $2011 / 6 / 29$ & Irrigation period & $\begin{array}{l}\text { Flooded } \\
\text { (0 day) }\end{array}$ & $\begin{array}{l}\text { Flooded } \\
\text { (7 day) }\end{array}$ & $\begin{array}{l}\text { Flooded } \\
\text { (3 day) }\end{array}$ \\
\hline $2011 / 11 / 28$ & Non-irrigation period & $\begin{array}{c}\text { Flooded } \\
\text { ( } 2 \text { day) }\end{array}$ & $\begin{array}{c}\text { Dried } \\
\text { (4 day) }\end{array}$ & $\begin{array}{l}\text { Flooded } \\
\text { ( } 2 \text { day) }\end{array}$ \\
\hline $2012 / 6 / 27$ & Irrigation period & $\begin{array}{l}\text { Flooded } \\
\text { (4 day) }\end{array}$ & $\begin{array}{l}\text { Flooded } \\
\text { (1 day) }\end{array}$ & $\begin{array}{l}\text { Flooded } \\
\text { (4 day) }\end{array}$ \\
\hline $2012 / 11 / 27$ & Non-irrigation period & $\begin{array}{c}\text { Flooded } \\
\text { (rainy day) }\end{array}$ & $\begin{array}{c}\text { Flooded } \\
\text { (rainy day) }\end{array}$ & $\begin{array}{c}\text { Flooded } \\
\text { (rainy day) }\end{array}$ \\
\hline
\end{tabular}

The number in parenthesis represents the number of dry days. 


\section{Phosphorus adsorption onto the sediment}

To clarify the characteristics of $\mathrm{P}$ adsorption/release of the sediments and the effect of drying on their characteristics, $\mathrm{P}$ adsorption experiment was conducted using wet and dry sediments. Sediments were collected from the $0-10 \mathrm{~cm}$ depth with a core sampler at each site during the non-irrigation period, packed into polyethylene bags, and stored at $4^{\circ} \mathrm{C}$ in a refrigerator. Water content of the sediment at each site (Site 1,2 and 3) was 162,80 , and $54 \%$, respectively. Part of the sediments was dried in an oven at $110^{\circ} \mathrm{C}$ overnight. Into $50 \mathrm{~mL}$ of phosphate solution (containing $0.00,0.01,0.03,0.05,0.10$, $0.30,0.50$, or $1.00 \mathrm{mgP} / \mathrm{L}$ as $\mathrm{KH}_{2} \mathrm{PO}_{4}$ ), $500 \mathrm{mg}$ of wet and dried sediments were added. The suspensions were shaken in an orbital shaker for $24 \mathrm{~h}$ at $25^{\circ} \mathrm{C}$ in an incubator. Then, the water was filtered through a $0.45-\mu \mathrm{m}$ filter. The experiment was conducted in duplicate. The amount of $\mathrm{P}$ adsorbed on the sediment was estimated from the difference between the initial and equilibrium concentrations:

$Q=\left(C_{\mathrm{i}}-C_{\mathrm{e}}\right) v / m$

where $Q$ is the amount of $\mathrm{PO}_{4}-\mathrm{P}$ absorbed on the sediment $(\mathrm{mgP} / \mathrm{g}), C_{\mathrm{i}}$ and $C_{\mathrm{e}}$ are the initial and equilibrium concentrations in the solution $(\mathrm{mgP} / \mathrm{L})$, respectively, $v$ is the volume of water $(0.05 \mathrm{~L})$, and $m$ is the dry weight of the sediment $(\mathrm{g})$. The linear isotherm model was used to describe $\mathrm{PO}_{4}$-P adsorption on the sediment:

$Q=K_{\mathrm{D}} C_{\mathrm{e}}-Q_{\mathrm{NAP}}$

where $K_{\mathrm{D}}$ is the adsorption equilibrium constant $(\mathrm{L} / \mathrm{g})$ and $Q_{\mathrm{NAP}}$ is the native adsorbed $\mathrm{PO}_{4}-\mathrm{P}(\mathrm{mgP} / \mathrm{g})$. Because the sediments already had some $\mathrm{P}\left(Q_{\mathrm{NAP}}>0\right), \mathrm{P}$ can be released $(Q<0)$ when the initial $\mathrm{PO}_{4}-\mathrm{P}$ concentration is low. The linear model can be used to describe equilibrium at low $\mathrm{PO}_{4}-\mathrm{P}$ concentrations and to estimate the zero-equilibrium $\mathrm{P}$ concentration $\left(\mathrm{EPC}_{0}\right)$ (Froelich, 1988) between the overlying water and the sediment. When $C_{\mathrm{e}}=\mathrm{EPC}_{0}$ then $Q=0$, i.e., there is no net $\mathrm{PO}_{4}-\mathrm{P}$ adsorption or release between the overlying water and the sediment (Klotz, 1988).

\section{Phosphorus released from the incubated sediment}

Sediment incubation experiments were conducted to simulate the $\mathrm{P}$ release from the sediment to the overlying water using intact sediment cores sampled at the study sites. Two intact sediment cores of $20 \mathrm{~cm}$ depth were collected in clear acrylic pipes (inner diameter $=40 \mathrm{~mm}$, height $=1,000 \mathrm{~mm}$ ) at each site in September 2012 (non-irrigation period). The cores were packed in ice to keep them cool and delivered to the laboratory. Within a day after sampling, the drainage water lying on the sediments was removed by syringe and then $500 \mathrm{~mL}$ of distilled water was gently added to prevent resuspension of the sediments. The water depth over the sediment surface was about $40 \mathrm{~cm}$. The cores were incubated for 30 days at a constant temperature of $20 \pm 1^{\circ} \mathrm{C}$ in the dark. The overlying water was sampled at $10 \mathrm{~cm}$ above the sediment surface by syringe with a tube at 1, 2, 3, 5, 7, 15, 20, 25, and 30 days from the start of incubation. Each time, 20 $\mathrm{mL}$ was sampled and then replaced with the same quantity of distilled water. The samples were filtered through $0.45-\mu \mathrm{m}$ cellulose acetate membrane filters and analyzed for $\mathrm{PO}_{4}-\mathrm{P}$. The concentration of $\mathrm{PO}_{4}-\mathrm{P}$ was presented as the mean of the two samples at each site. It was assumed the distilled water made a $4 \%$ decrease in subsequent concentrations and reanalyzed the concentration of $\mathrm{PO}_{4}-\mathrm{P}$. 
To measure the change of $\mathrm{P}$ in the sediment during the incubation, 12 sediment cores of $10 \mathrm{~cm}$ depth were collected using clear acrylic pipes (inner diameter $=91 \mathrm{~mm}$, height $=$ $300 \mathrm{~mm}$ ) at each site in July 2013 (irrigation period). The drainage water lying on the sediments was removed in situ by syringe. The cores were packed in ice during the delivery to the laboratory and then $600 \mathrm{~mL}$ of distilled water was gently added to the sediments. The water depth over the sediment surface was about $10 \mathrm{~cm}$. The cores were incubated for $7,14,21,28$ days at a constant temperature of $20 \pm 1{ }^{\circ} \mathrm{C}$ in the dark. The experiments were performed in triplicate (i.e., a total of 36 cores $=3$ sediments (sites) $\times$ 4 incubation periods $\times$ triplicate). After the incubation periods, the overlying water was removed and the $\mathrm{P}$ fractions of the surface sediment $(0-1 \mathrm{~cm})$ were measured according to the sequential extraction method of Psenner et al. (1988), which was partially modified in this study. In summary, the $\mathrm{P}$ fractions were sequentially extracted by the following solutions: deionized water, but $\mathrm{NH}_{4} \mathrm{Cl}$ solution was originally used in the Psenner method; $0.1 \mathrm{M} \mathrm{Na}_{2} \mathrm{~S}_{2} \mathrm{O}_{4}$ and $0.1 \mathrm{M} \mathrm{NaHCO}_{3}$ solution; $1 \mathrm{M} \mathrm{NaOH}$ solution; $0.5 \mathrm{M} \mathrm{HCl}$ solution; and $1 \mathrm{M} \mathrm{HCl}$ solution after ignition in an oven at $550^{\circ} \mathrm{C}$. The extracted $\mathrm{P}$ concentrations were measured as $\mathrm{PO}_{4}-\mathrm{P}$ by the molybdenum blue method. By the modified Psenner method, $\mathrm{P}$ fractions were divided into $\mathrm{P}$ that was easily released from the sediment under natural conditions (water-extractable $\mathrm{PO}_{4}-\mathrm{P}$ : WE-P); $\mathrm{P}$ released under reducing conditions $\left(\mathrm{Na}_{2} \mathrm{~S}_{2} \mathrm{O}_{4}-\mathrm{NaHCO}_{3}\right.$-extractable $\mathrm{PO}_{4}-\mathrm{P}$ : DB-P); $\mathrm{P}$ released under high $\mathrm{pH}$ conditions $\left(\mathrm{NaOH}-\right.$ extractable $\left.\mathrm{PO}_{4}-\mathrm{P}: \mathrm{NaOH}-\mathrm{P}\right) ; \mathrm{P}$ released under low $\mathrm{pH}$ conditions $\left(\mathrm{HCl}-\right.$ extractable $\mathrm{PO}_{4}-\mathrm{P}$ : $\left.\mathrm{HCl}-\mathrm{P}\right)$; and residual $\mathrm{P}$ that was strongly trapped in the sediment $\left(\mathrm{PO}_{4}-\mathrm{P}\right.$ extracted with $\mathrm{HCl}$ after ignition). In addition, the $\mathrm{pH}$ and ORP in the overlying water of the sediments, of which were incubated for 28 days, were measured using a pH/ORP meter (D-54, Horiba Ltd., Tokyo, Japan). In this paper, however, the results on Site 1 are not discussed because TSP at Site 1 in 2013 was high $(3.0-5.7 \mathrm{mgP} / \mathrm{g})$ compared to the previous results, although the reason is still unclear.

\section{RESULTS AND DISCUSSION}

\section{Phosphorus in the drainage water and sediment}

Most T-P concentrations at Site 1 and Site 3 ranged between 0.1 and $0.2 \mathrm{mgP} / \mathrm{L}$. Concentrations of all three $\mathrm{P}$ fractions tended to be higher at Site 2 than at Site 1 and Site 3. The concentration of particulate $\mathrm{P}$ can be estimated as the difference between T-P and TD-P. Total dissolved P accounted for less than half of T-P (Table 3), suggesting that most $\mathrm{P}$ in the drainage water was particulate. The concentration of dissolved organic $\mathrm{P}$ can be estimated as the difference between TD-P and $\mathrm{PO}_{4}-\mathrm{P}$. The differences were low, suggesting that TD-P was mainly inorganic.

Total sedimentary P tended to decrease with depth (Table 4). Total sedimentary P was highest in the upper sediment at Site $1(1.92 \mathrm{mgP} / \mathrm{g})$, followed by Site 3 and Site 2 . On the other hand, TSP of the lower sediments was $0.50-0.70 \mathrm{mgP} / \mathrm{g}$, with a smaller variation than in the upper sediments. Total sedimentary $\mathrm{P}$ values were comparable to those in trophic lakes, in which TSP of the surface sediments was around $0.5-1.5$ $\mathrm{mgP} / \mathrm{g}$ (Wang et al., 2009). 
Table 3 - pH, suspended solids and phosphorus concentrations in the drainage water measured during the field investigation (mean \pm standard deviation).

\begin{tabular}{lccccc}
\hline & $\mathrm{pH}$ & $\mathrm{SS}$ & $\mathrm{T}-\mathrm{P}$ & $\mathrm{TD}-\mathrm{P}$ \\
{$[\mathrm{mg} / \mathrm{L}]$} & {$[\mathrm{mgP} / \mathrm{L}]$} & $\begin{array}{c}\mathrm{PO}_{4}-\mathrm{P} \\
{[\mathrm{mgP} / \mathrm{L}]}\end{array}$ & {$[\mathrm{mgP} / \mathrm{L}]$} \\
\hline Site 1 $(n=20)$ & $7.17 \pm 0.69$ & $12 \pm 14$ & $0.11 \pm 0.08$ & $0.03 \pm 0.01$ & $0.02 \pm 0.01$ \\
Site 2 $(n=14)$ & $7.12 \pm 0.72$ & $16 \pm 21$ & $0.28 \pm 0.24$ & $0.10 \pm 0.05$ & $0.07 \pm 0.04$ \\
Site 3 $(n=18)$ & $7.14 \pm 0.77$ & $18 \pm 24$ & $0.14 \pm 0.06$ & $0.06 \pm 0.05$ & $0.05 \pm 0.04$ \\
\hline
\end{tabular}

Table 4 - Total sedimentary phosphorus in the sediments measured during the field investigation (mean \pm standard deviation).

\begin{tabular}{lccc}
\hline & $\begin{array}{c}\text { Site } 1 \\
{[\mathrm{mgP} / \mathrm{g}]}\end{array}$ & $\begin{array}{c}\text { Site 2 } \\
{[\mathrm{mgP} / \mathrm{g}]}\end{array}$ & $\begin{array}{c}\text { Site 3 } \\
{[\mathrm{mgP} / \mathrm{g}]}\end{array}$ \\
\hline Upper $(0-1 \mathrm{~cm})$ & $1.92 \pm 0.80$ & $0.82 \pm 0.14$ & $1.36 \pm 0.52$ \\
Middle $(1-5 \mathrm{~cm})$ & $1.07 \pm 0.68$ & $0.65 \pm 0.03$ & $0.73 \pm 0.06$ \\
Lower $(5-10 \mathrm{~cm})$ & $0.70 \pm 0.18$ & $0.50 \pm 0.08$ & $0.61 \pm 0.11$ \\
\hline Core $(0-10 \mathrm{~cm}) *$ & $0.97 \pm 0.33$ & $0.59 \pm 0.0$ & $0.73 \pm 0.08$ \\
\hline * Core $=$ weighted mean of total P of the sediments.
\end{tabular}

\section{Phosphorus adsorption isotherm}

In the ranges of the equilibrium $\mathrm{P}$ concentration, in which the linear isotherm model can describe the $\mathrm{P}$ adsorption characteristics well; i.e., $0.0-0.04 \mathrm{mgP} / \mathrm{L}$ (Site 1), $0.0-0.5$ $\mathrm{mgP} / \mathrm{L}$ (Site 2), and $0.0-0.1 \mathrm{mgP} / \mathrm{L}$ (Site 3), the concentrations of $\mathrm{P}$ adsorbed on the sediments were $-0.02-0.1 \mathrm{mgP} / \mathrm{kg}$ (Fig. 2). Drying treatment caused clear change in the characteristics of the sediments, especially at Site 1 . The $x$-intercept and the slope of the linear isotherm increased after drying.

Table 5 shows $x$-intercept $\left(\mathrm{EPC}_{0}\right)$ and the slope $\left(K_{\mathrm{D}}\right)$ of the linear isotherm. The $\mathrm{EPC}_{0}$ of the wet sediments was $0.006 \mathrm{mgP} / \mathrm{L}$ at Site $1,0.11 \mathrm{mgP} / \mathrm{L}$ at Site 2, and $0.006 \mathrm{mgP} / \mathrm{L}$ at Site 3 (Table 3). In another paddy-field district near Lake Biwa, the sediment in a drainage canal had an $\mathrm{EPC}_{0}$ of $0.004-0.027 \mathrm{mgP} / \mathrm{L}$ (Sugiyama and Hama, 2013). Therefore, the sediments at Site 1 and Site 3 had lower $\mathrm{EPC}_{0}$ than other sediments in agricultural drainage canals. When the actual $\mathrm{PO}_{4}-\mathrm{P}$ concentration in the overlying water is lower than $\mathrm{EPC}_{0}, \mathrm{PO}_{4}-\mathrm{P}$ is released from the sediment, and the drainage canal may act as a $\mathrm{P}$ source (Sugiyama and Hama, 2013). Thus, higher $\mathrm{EPC}_{0}$ values indicate that $\mathrm{PO}_{4}-\mathrm{P}$ is easily released, increasing the risk that the sediments may become a source of $\mathrm{PO}_{4}-\mathrm{P}$. The sediment at Site 2 had a high $\mathrm{EPC}_{0}$, suggesting that it may act as a source, and the $\mathrm{PO}_{4}-\mathrm{P}$ concentration may increase as the water flows through the drainage canal. On the other hand, the sediment at Site 3 had a lower $\mathrm{EPC}_{0}$ than the mean $\mathrm{PO}_{4}-\mathrm{P}$ concentrations in the drainage water (Table 3) and could decrease the $\mathrm{PO}_{4}-\mathrm{P}$ concentrations.

We had assumed that the $\mathrm{EPC}_{0}$ in this study, especially at Site 1, where the sediment was submerged all year round, could be underestimated because the drying might partially oxidize the sediments, increasing their $\mathrm{P}$ adsorption capacity (House and Denison, 2000; Palmer-Felgate et al., 2011). However, EPC ${ }_{0}$ of the dry sediments was 
higher than that of the wet sediments (Table 5). This result suggests that drying may increase the risk of the sediment as a $\mathrm{P}$ source. The reason is not clear and further research is necessary.

The $K_{\mathrm{D}}$ value indicates the attraction of the sediment toward P; i.e., a higher $K_{\mathrm{D}}$ indicates that more $\mathrm{P}$ will be adsorbed (Reddy et al., 1995; Smith et al., 2006; Haggard et al., 2007). By comparing with $K_{\mathrm{D}}$ values obtained in previous researches (Table 6), it was confirmed that the P-buffering capacity of the drainage canal sediments was high. Some researches (Smith et al., 2005; Haggard et al., 2007) reported that the P-buffering capacity of the sediments increased with the fractions of fine particle (silt and clay). The higher $K_{\mathrm{D}}$ of the drainage canal sediments could be due to higher percentage of fine particle, which was more than $60 \%$. The P-buffering capacity of the sediment was increased by dying treatment. The $K_{\mathrm{D}}$ value of the dried sediments at all sites was higher than that of the wet sediments.

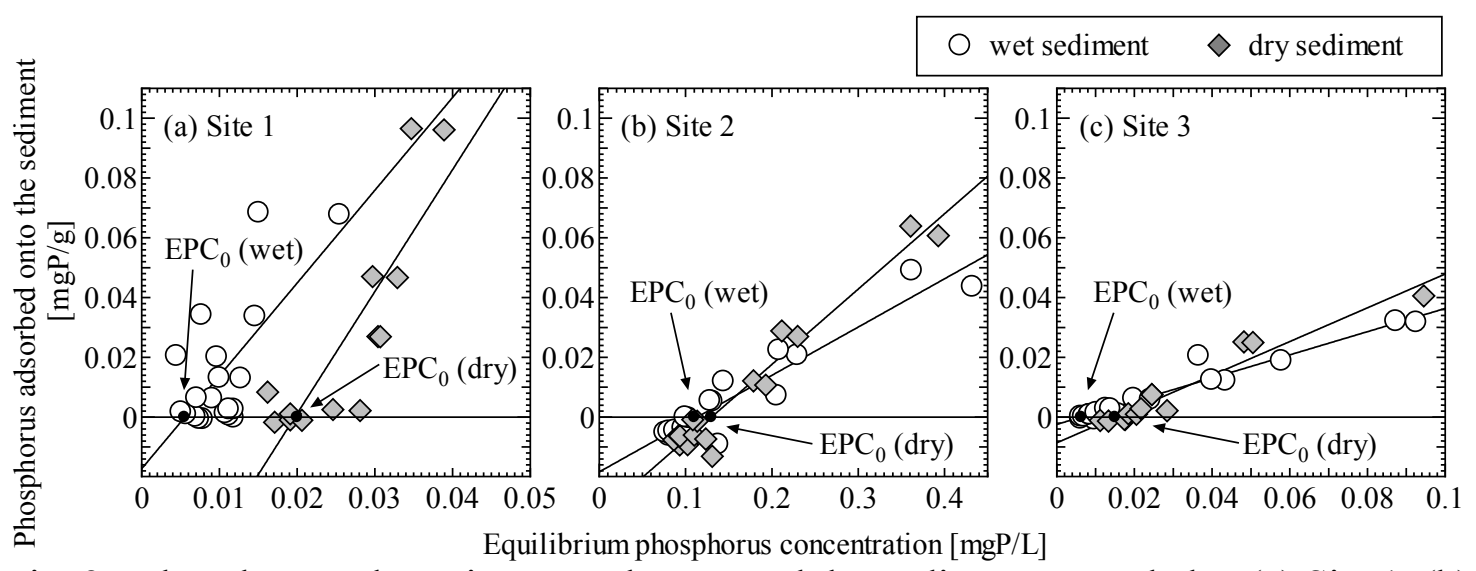

Fig. 2 - Phosphorus adsorption onto the wet and dry sediments sampled at (a) Site 1, (b)

Site 2, and (c) Site 3. Solid lines are the linear isotherms of the sediments.

Table 5 - Zero-equilibrium phosphorus concentration $\left(\mathrm{EPC}_{0}\right)$ and buffering capacity of the wet and dry sediments estimated from the linear isotherm model.

\begin{tabular}{lccccccccc}
\hline & \multicolumn{6}{l}{ Wet sediment } & & Dry sediment \\
\cline { 2 - 3 } & $\begin{array}{c}\mathrm{EPC}_{0} \\
{[\mathrm{mgP} / \mathrm{L}]}\end{array}$ & $\begin{array}{c}K_{\mathrm{D}} \\
{[\mathrm{L} / \mathrm{g}]}\end{array}$ & $\begin{array}{c}Q_{\mathrm{NAP}} \\
{[\mathrm{mgP} / \mathrm{g}]}\end{array}$ & $\mathrm{R}^{2}$ & $\begin{array}{c}\mathrm{EPC}_{0} \\
{[\mathrm{mgP} / \mathrm{L}]}\end{array}$ & $\begin{array}{c}K_{\mathrm{D}} \\
{[\mathrm{L} / \mathrm{g}]}\end{array}$ & $\begin{array}{c}Q_{\mathrm{NAP}} \\
{[\mathrm{mgP} / \mathrm{g}]}\end{array}$ & $\mathrm{R}^{2}$ \\
\hline Site 1 & 0.006 & 3.1 & $1.7 \times 10^{-2}$ & 0.46 & 0.020 & 4.1 & $8.0 \times 10^{-2}$ & 0.72 \\
Site 2 & 0.110 & $1.6 \times 10^{-1}$ & $1.8 \times 10^{-2}$ & 0.90 & 0.130 & $2.5 \times 10^{-1}$ & $3.3 \times 10^{-2}$ & 0.95 \\
Site 3 & 0.006 & $3.9 \times 10^{-1}$ & $2.4 \times 10^{-3}$ & 0.95 & 0.015 & $5.7 \times 10^{-1}$ & $8.6 \times 10^{-3}$ & 0.93 \\
\hline
\end{tabular}

Table 6 - Comparison of the P-buffering capacity $\left(\mathrm{K}_{\mathrm{D}}\right)$.

\begin{tabular}{|c|c|c|c|c|c|c|c|c|}
\hline & \multicolumn{4}{|c|}{ Wet sediment } & \multicolumn{4}{|c|}{ Dry sediment } \\
\hline & $\begin{array}{c}\mathrm{EPC}_{0} \\
{[\mathrm{mgP} / \mathrm{L}]}\end{array}$ & $\begin{array}{c}K_{\mathrm{D}} \\
{[\mathrm{L} / \mathrm{g}]}\end{array}$ & $\begin{array}{c}Q_{\mathrm{NAP}} \\
{[\mathrm{mgP} / \mathrm{g}]}\end{array}$ & $\mathrm{R}^{2}$ & $\begin{array}{c}\mathrm{EPC}_{0} \\
{[\mathrm{mgP} / \mathrm{L}]}\end{array}$ & $\begin{array}{c}K_{\mathrm{D}} \\
{[\mathrm{L} / \mathrm{g}]}\end{array}$ & $\begin{array}{c}Q_{\mathrm{NAP}} \\
{[\mathrm{mgP} / \mathrm{g}]}\end{array}$ & $\mathrm{R}^{2}$ \\
\hline Site 1 & 0.006 & 3.1 & $1.7 \times 10^{-2}$ & 0.46 & 0.020 & 4.1 & $8.0 \times 10^{-2}$ & 0.72 \\
\hline Site 2 & 0.110 & $1.6 \times 10^{-1}$ & $1.8 \times 10^{-2}$ & 0.90 & 0.130 & $2.5 \times 10^{-1}$ & $3.3 \times 10^{-2}$ & 0.95 \\
\hline Site 3 & 0.006 & $3.9 \times 10^{-1}$ & $2.4 \times 10^{-3}$ & 0.95 & 0.015 & $5.7 \times 10^{-1}$ & $8.6 \times 10^{-3}$ & 0.93 \\
\hline
\end{tabular}




\section{Phosphorus released from the sediment}

The concentrations of $\mathrm{PO}_{4}-\mathrm{P}$ released from the sediments increased with time to a peak at 25 - 30 days after the start of the experiment (Fig. 3). The peak concentrations were $0.02 \mathrm{mgP} / \mathrm{L}$ (Site 1), $0.11 \mathrm{mgP} / \mathrm{L}$ (Site 2), and $0.017 \mathrm{mgP} / \mathrm{L}$ (Site 3). These peaks were similar to mean $\mathrm{PO}_{4}-\mathrm{P}$ concentrations in the drainage water in the field (Table 3).

The $\mathrm{EPC}_{0}$ of each sediment (Table 5) was also similar to the concentration of $\mathrm{PO}_{4}-\mathrm{P}$ released (Fig. 3). This indicates that the role of $\mathrm{P}$ uptake or decomposition by microorganisms on $\mathrm{P}$ dynamics is small compared with the release of $\mathrm{P}$ from the sediments, because $\mathrm{EPC}_{0}$ was calculated from a short-term adsorption experiment using dry sediment, in which biological processes are likely to be limited. House and Denison (1997) concluded that $\mathrm{EPC}_{0}$ in the top $5 \mathrm{~cm}$ of sediment was a valuable indicator of the direction of the P flux when biological processes were minimal. However, as shown in the incubation experiments (Fig. 3), the sediments may release $\mathrm{PO}_{4}-\mathrm{P}$ slowly. Therefore, it can be concluded that the sediments determine the $\mathrm{PO}_{4}-\mathrm{P}$ concentrations in drainage water flowing slowly through the canal, though not in large runoff events. Additionally, the values of the peak concentrations were not consistent with the size of TSP (Table 4), suggesting that the size of total $\mathrm{P}$ of the sediments is not suitable for an indicator of $\mathrm{P}$ release risk.

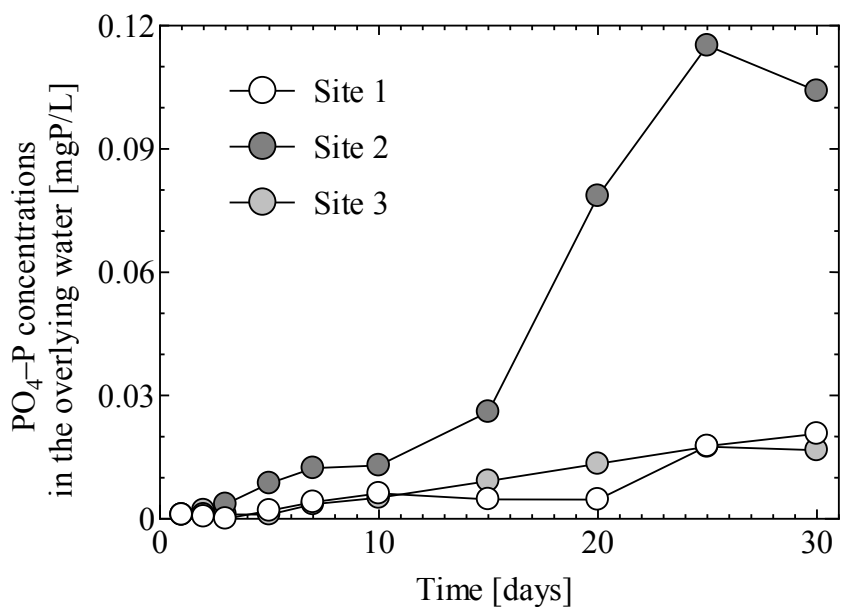

Fig. 3 - Temporal variations in the concentrations of $\mathrm{PO}_{4}-\mathrm{P}$ released from the incubated sediments sampled at Site 1, Site 2, and Site 3. 


\section{Phosphorus fractions in the incubated sediments}

The WE-P value represents the most soluble $\mathrm{P}$ fraction in soils and can be used to evaluate the risk of $\mathrm{P}$ loss from agricultural lands (Sharpley and Moyer, 2000; Kleinman et al., 2005; Iwasaki et al., 2013). Figure 3 suggests that the sediments of Site 2 could release large amount of $\mathrm{PO}_{4} \mathrm{P}$ to the overlying water. However, the concentrations of WE-P in the sediments of Site 2 did not change with the incubation periods (Fig. 4). On the other hand, the WE-P in the sediments of Site 3 decreased by 55\% (from 0.0084 to $0.0038 \mathrm{mgP} / \mathrm{g}$ ).

The contribution of the WE-P can be simply estimated by the following equation:

$C_{\text {WE-P }}=Q_{\text {WE-P }} \rho_{\mathrm{s}} v_{\mathrm{s}} / v$

where $C_{\text {WE-P }}$ is the P concentration determined by the WE-P released from sediment, $Q_{\text {WE-P }}$ is the amount of the WE-P, $\rho_{\mathrm{s}}$ is the density of sediment, and $v_{\mathrm{s}}$ and $v$ are the volume of sediment and the overlying water, respectively. When the value of $r_{\mathrm{s}}$ is 2.65 $\left(\mathrm{g} / \mathrm{cm}^{3}\right)$, which is a commonly used value for soil and $Q_{\text {WE-P }}$ is $0.0046(\mathrm{mgP} / \mathrm{g})$, the decrease of WE-P at Site 3 (Fig.4) then the " $Q_{\text {WE-P }} \rho_{\mathrm{s}}$ " becomes about $12 \mathrm{mgP} / \mathrm{L}$. The sediment/water ratio $\left(v_{\mathrm{s}} / v\right)$ ranging from $1: 1000$ to $1: 500$ can make $C_{\text {WE-P }}=0.01-0.02$ $\mathrm{mgP} / \mathrm{L}$, which is equivalent to the released $\mathrm{P}$ concentration (Fig. 3). This result suggests that $1 \mathrm{~cm}$ of the sediment can affect $5-10 \mathrm{~m}$ of the overlying water. Therefore, the WE-P fraction might be a $\mathrm{PO}_{4}-\mathrm{P}$ source in the sediments of Site 3 .

In the sediments of Site 2, the concentrations of DB-P were $0.81,1.02,1.21$, and 0.83 $\mathrm{mgP} / \mathrm{g}$ for day 7, 14, 21 and 28, respectively (Fig. 5). The DB-P value was the main fraction of the sediment $\mathrm{P}$ and respectively accounted for $49,71,77$, and $77 \%$ of TSP. But, the standard deviation of the DB-P concentration was large and there was no clear tendency for the relationship between the incubation period and the DB-P concentrations. This might be because the DB-P fraction was sensitive to the environmental factors such as dissolved oxygen and water temperature and their spatial variation in the sediments was large. In contrast, the concentrations of NaOH-P and HCl-P were low and stable.

In the incubated sediments of Site 3, the DB-P concentration after 7-day incubation period was $1.18 \mathrm{mgP} / \mathrm{g}$, which accounted for $58 \%$ of TSP (Fig. 6). Then, the concentrations of DB-P in the following days $(14,21$ and 28$)$ were $1.09 \mathrm{mgP} / \mathrm{g}(55 \%$ of TSP), $1.27 \mathrm{mgP} / \mathrm{g}(68 \%)$, and $1.08 \mathrm{mgP} / \mathrm{g}(50 \%)$, respectively. The concentrations of $\mathrm{NaOH}-\mathrm{P}$ seem to slightly decrease with the incubation period $(0.53,0.47,0.48$, and 0.41 $\mathrm{mgP} / \mathrm{g}$, respectively).

The $\mathrm{pH}$ in the overlying water of the 28-day-incubated sediments increased with time (Fig.7). However, the effect of flooding on the NaOH-P and HCl-P fractions might be small because $\mathrm{pH}$ during the incubation period was near neutral. The ORP in the overlying water decreased from 350 to $105 \mathrm{mV}$ (Site 2) and from 349 to $50 \mathrm{mV}$ (Site 3). Under reducing condition (ORP $<200 \mathrm{mV}$ ), P could be released from the sediment associated with the reduction of iron oxide (Bström et al., 1988). 


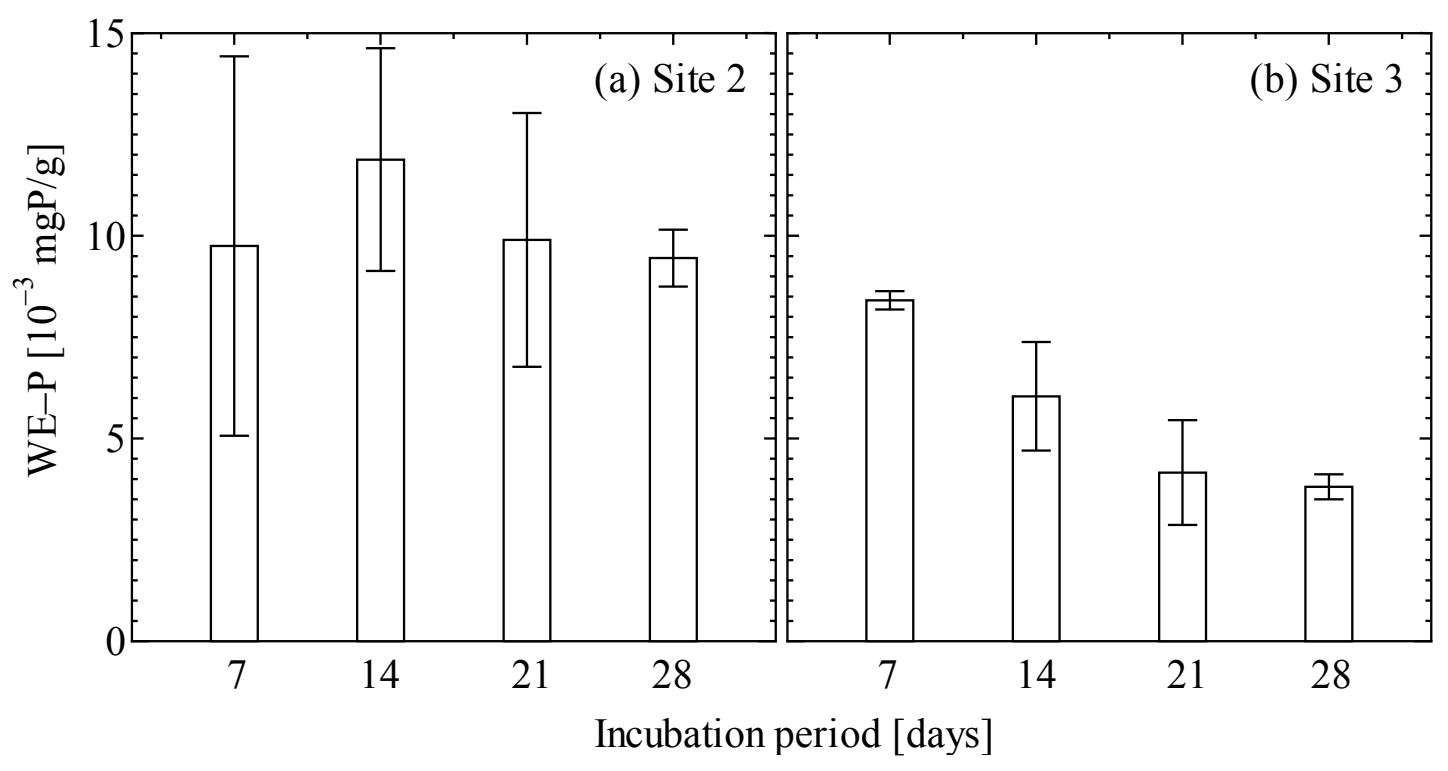

Fig. 4 - Concentrations of water-extractable $\mathrm{PO}_{4}-\mathrm{P}(\mathrm{WE}-\mathrm{P})$ in the sediments of (a) Site 2 and (b) Site 3 after each incubation period. The error bars indicate the standard deviation.

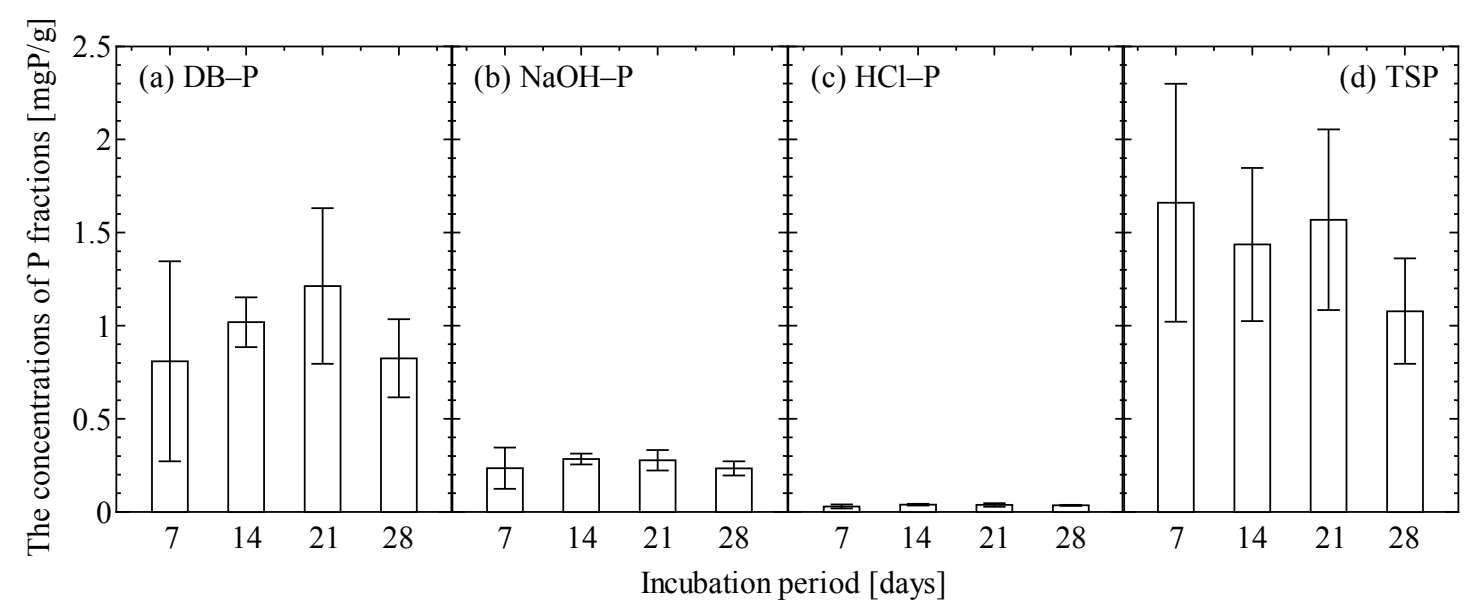

Fig. 5 - Concentrations of (a) $\mathrm{Na}_{2} \mathrm{~S}_{2} \mathrm{O}_{4}-\mathrm{NaHCO}_{3}$-extractable $\mathrm{PO}_{4}-\mathrm{P}$ (DB-P), (b) $\mathrm{NaOH}-$ extractable $\mathrm{PO}_{4}-\mathrm{P}(\mathrm{NaOH}-\mathrm{P})$, (c) $\mathrm{HCl}-$ extractable $\mathrm{PO}_{4}-\mathrm{P}$ (HCl-P), and (d) total sedimentary P (TSP) in the sediments of Site 2 after each incubation period. The error bars indicate the standard deviation. 


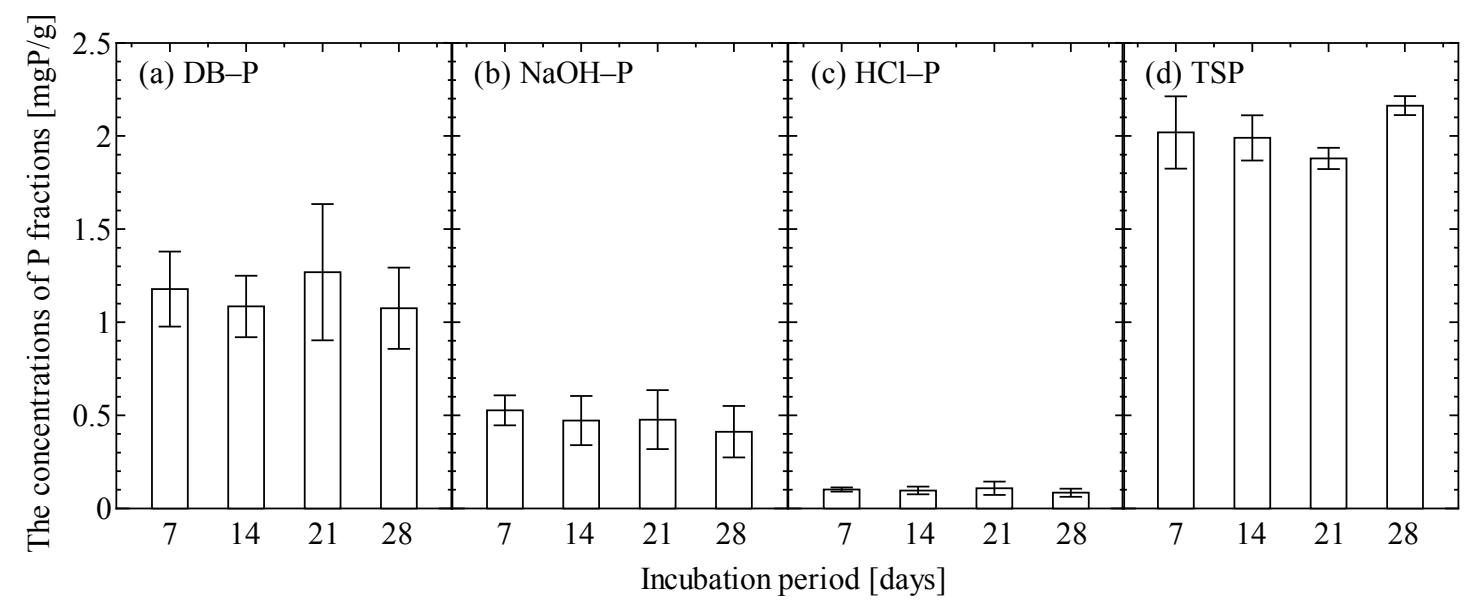

Fig. 6 - Concentrations of (a) $\mathrm{Na}_{2} \mathrm{~S}_{2} \mathrm{O}_{4}-\mathrm{NaHCO}_{3}$-extractable $\mathrm{PO}_{4}-\mathrm{P}$ (DB-P), (b) $\mathrm{NaOH}-$ extractable $\mathrm{PO}_{4}-\mathrm{P}(\mathrm{NaOH}-\mathrm{P})$, (c) $\mathrm{HCl}-$ extractable $\mathrm{PO}_{4}-\mathrm{P}(\mathrm{HCl}-\mathrm{P})$, and (d) total sedimentary P (TSP) in the sediments of Site 3 after each incubation period. The error bars indicate the standard deviation.
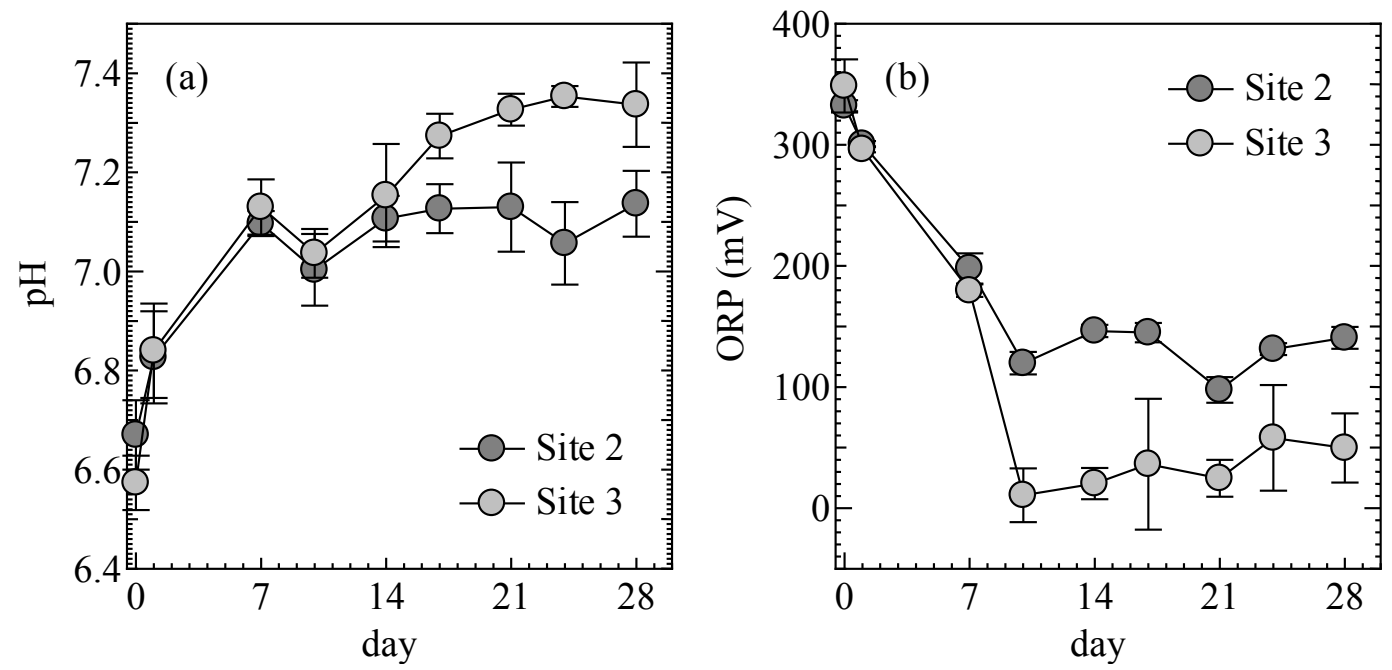

Fig. 7 - Temporal variations in (a) $\mathrm{pH}$ and (b) ORP in the overlying water of the 4-week-incubated sediments at Site 2 and Site 3. The error bars indicate the standard deviation.

In this study, we could not find significant $\mathrm{P}$ release from the DB-P fractions in the sediments. However, the DB-P fractions are also important as a potential $\mathrm{P}$ source because the concentrations of the DB-P accounted for over $50 \%$ of the total $\mathrm{P}$ in the sediments and can be released under reducing condition. We believe that the DB-P can be a main $\mathrm{P}$ source when the overlying drainage water is stagnant for a long time (over a month). Further research is needed to clarify the characteristics of the DB-P in the drainage canal sediments. 


\section{CONCLUSIONS}

The sediments in the drainage canals in three paddy-field districts had a large $\mathrm{P}$ buffering capacity. The zero-equilibrium phosphorus concentrations $\left(\mathrm{EPC}_{0}\right)$ of the sediments were similar to the peak concentrations of $\mathrm{PO}_{4}-\mathrm{P}$ released from the incubated sediments and the mean $\mathrm{PO}_{4}-\mathrm{P}$ concentrations in the drainage water. These results suggest that the sediments determine the concentrations of $\mathrm{PO}_{4}-\mathrm{P}$ in the overlying drainage water. The $\mathrm{EPC}_{0}$ and WE-P of the sediments can be a good indicator to estimate $\mathrm{P}$ release from the sediments.

\section{ACKNOWLEDGEMENTS}

This study was partly funded by JSPS KAKENHI Grant Number 24780231 and by a research fund from Kumamoto Ground Water Foundation.

\section{REFERENCES}

Barlow K., Fenton J., Nash D. and Grayson R. (2006) Modelling phosphorus transport in a surface irrigation drain. Adv. Water Resour., 29, 1383-1398.

Bström B., Andersen J. M., Fleischer S. and Jansson M. (1988) Exchange of phosphorus across the sediment-water interface. Hydrobiologia, 170(1), 229-244.

Froelich P. N. (1988) Kinetic control of dissolved phosphate is natural rivers and estuaries: A primer on the phosphate buffer mechanism. Limnol. Oceanogr., 33, 649-668.

Haggard B. E., Smith D. R. and Brye K. R. (2007) Variations in stream water and sediment phosphorus among select Ozark Catchments. J. Environ. Qual., 36, $1725-1734$.

Hama T., Aoki T., Osuga K., Sugiyama S. and Iwasaki D. (2013) Reducing the phosphorus effluent load from a paddy-field district through cyclic irrigation. Ecol. Eng., 54, 107-115.

Hama T., Iwasaki D., Nagai T., Igarashi F., Kawagoshi Y. and Ozaki H. (2014) Effect of bioturbation by tubificid worms on nutrient release from the sediment in an agricultural drainage canal. J. Water Environ. Technol., 12(3), 297-307.

House W. A. and Denison F. H. (2000) Factors influencing the measurement of equilibrium phosphate concentrations in river sediments. Water Res., 34, 1187-1200.

House W. A. and Denison F. H. (1997) Nutrient dynamics in a lowland stream impacted by sewage effluent: Great Ouse, England. Sci. Total Environ., 205, 25-49.

Iwasaki D., Hama T., Osuga K. and Sugiyama S. (2013) Characteristics of phosphorus in sediments in drainage canals in paddy-field districts around Lake Biwa. J. Water Environ. Technol., 11(2), 81-89.

JMA (Japan Meteorological Agency) (2014) AMeDAS. Japan Meteorological Agency, Tokyo, Japan. (http://www.jma.go.jp/jma/, accessed on 2014 May 15)

Kleinman P. J. A., Wolf A. M., Sharpley A. N., Beegle D. B. and Saporito L. S. (2005) Survey of water-extractable phosphorus in livestock manures. Soil Sci. Soc. Am. J., 69, 701-708.

Klotz R. L. (1988) Sediment control of soluble reactive phosphorus in Hoxie Gorge Creek, New York. Can. J. Fish. Aquat. Sci., 45, 2026-2034.

Kröger L., Holland M. M., Moore M. T. and Cooper C. M. (2008) Agricultural drainage ditches mitigate losses of phosphorus loads as a function of hydrological variability. 


\section{J. Environ. Qual., 37, 107-113.}

Lin C., Wang Z., He M., Li Y., Liu R. and Yang Z. (2009) Phosphorus sorption and fraction characteristics in the upper, middle and low reach sediments of the Daliao river systems, China. J. Hazard. Mater, 170, 278-285.

Murphy J. and Riley J. P. (1962) A modified single solution method for the determination of phosphorus in natural waters. Anal. Chim. Acta, 12, 31-36.

Nguyen L. and Sukias J. (2002) Phosphorus fractions and retention in drainage ditch sediments receiving surface runoff and subsurface drainage from agricultural catchments in the North Island, New Zealand. Agric. Ecosys. Environ., 92, 49-69.

Palmer-Felgate E. J., Bowes M. J., Stratford C., Neal C. and MacKenzie S. (2011) Phosphorus release from sediments in a treatment wetland: Contrast between DET and $\mathrm{EPC}_{0}$ methodologies. Ecol. Eng., 37, 826-832.

Psenner R., Böstrom B., Dinka M., Petterson K., Pucsko R. and Sager M. (1988) Fractionation of phosphorus in suspended matter and sediment. Arch. Hydrobiol. Beih., 30, 98-110.

Reddy K. R., Diaz O. A., Scinto L. J. and Agami M. (1995) Phosphorus dynamics in selected wetlands and streams of the Lake Okeechobee Basin. Ecol. Eng., 5, 183-207.

Sharpley A. N. (1995) Soil phosphorus dynamics: agronomic and environmental impacts. Ecol. Eng., 5, 261-279.

Sharpley A. N. and Moyer B. (2000) Phosphorus forms in manure and compost and their release during simulated rainfall. J. Environ. Qual., 29, 1462-1469.

Smith D. R. (2009) Assessment of in-stream phosphorus dynamics in agricultural drainage ditches. Sci. Total Environ., 407, 3883-3889.

Smith D. R., Haggard B. E., Warnemuende E. A. and Huang C. (2005) Sediment phosphorus dynamics for three tile fed drainage ditches in Northeast Indiana. Agric. Water Manage., 71, 19-32.

Smith D. R., Warnemuende E. A., Haggard B. E. and Huang C. (2006) Changes in sediment-water column phosphorus interactions following sediment disturbance. Ecol. Eng., 27, 71-78.

Sugiyama S. and Hama T. (2013) Effects of water temperature on phosphate adsorption onto sediments in an agricultural drainage canal in a paddy-field district. Ecol. Eng., 61, 94-99.

Wang S., Jin X., Zhao H. and Wu F. (2009) Phosphorus release characteristics of different trophic lake sediments under simulative disturbing conditions. J. Hazard. Mater., 161, 95-105.

Wang S., Jin X., Zhao H., Zhou X. and Wu F. (2007) Effect of organic matter on the sorption of dissolved organic and inorganic phosphorus in lake sediments. Colloids Surf., A, 297, 154-162. 